\title{
Changes in Species Composition of Cladoceran Community in Lake Kasumigaura during 1986-1989: Occurrence of Daphnia galeata and Its Effect on Algal Biomass
}

\author{
Takayuki Hanazato and Morihiro Aizaki
}

\begin{abstract}
Seasonal changes of cladoceran community in Takahamairi Bay and the center region of Lake Kasumigaura were investigated from 1986 to 1989. The species composition of the cladoceran community was stable in summer, when Diaphanosoma brachyurum and Bosmina fatalis predominated. In contrast, during late fall-spring, it differed greatly among the years. This might be related to the predation by mysids, whose density also differed from year to year. The most marked change in species composition was the occurrence of Daphnia galeata, which had never been found in the lake before 1986 . The grazing by $D$. galeata seemed to greatly reduce the phytoplankton biomass in Lake Kasumigaura, since the chlorophyll $a$ concentration declined to very low levels when the daphnids became abundant. The birth rates of cladocerans were highest in summer. They tended to be higher in the shallower region than in the deeper one, indicating that the former was more productive for zooplankton.
\end{abstract}

Key words: cladoceran community, species composition, Daphnia, mysid, algal biomass, Lake Kasumigaura

\section{Introduction}

Seasonal changes of zooplankton community in Lake Kasumigaura from 1976 to 1985 have been reported by YASUNo et al. $(1977,1981)$, Morishita and Yasuno (1979) and Hanazato and YASUno (1988). The standing crop of zooplankton reached its highest level in summer, when cladocerans became dominant. The population dynamics and production of cladocerans were studied by Hanazato and Yasuno (1985a, 1987a), and the zooplankton community investigation has been continued thereafter. The present study demonstrates the changes in the cladoceran community from 1986 to 1989. During this study period, a new cladoceran species, Daphnia galeata, occurred and seemed to affect the algal biomass greatly.

\section{Methods}

Samplings were performed monthly at two stations in Takahamairi Bay and the center region of Lake Kasumigaura (Stas. 3 and 9: Fig. 1) from January 1986 through December 1989.

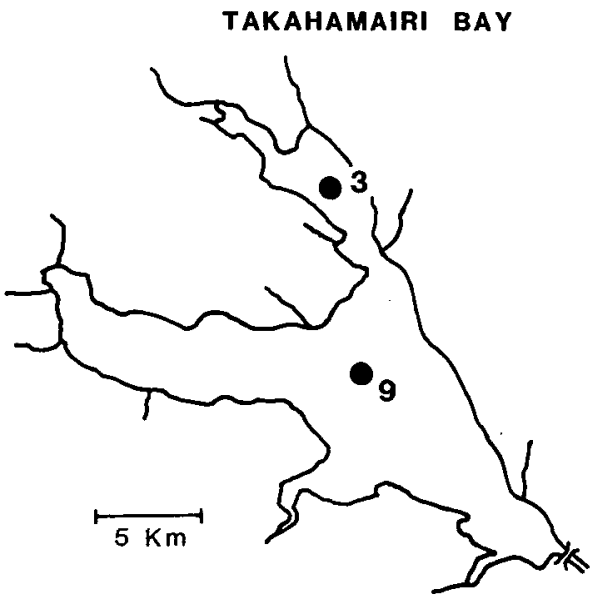

\section{LAKE KASUMIGAURA}

Fig. 1. Map of Lake Kasumigaura showing sampling stations. 
The water depth was about $4 \mathrm{~m}$ at Sta. 3 and was about $6 \mathrm{~m}$ at Sta. 9. Remarkable stratification of water temperature is not observed throughout a year in this shallow lake. Water samples were taken using and acrylic tube sampler (5 $\mathrm{cm}$ in diameter and $2 \mathrm{~m}$ in length) which isolated the water column from the surface to $2 \mathrm{~m}$ in depth. Cladoceran zooplankton were collected by filtering 10 liter of the sampled water through a $93 \mu \mathrm{m}$ mesh net from January 1986 to April 1987, and a $40 \mu \mathrm{m}$ mesh net from May 1987 to December 1989. They were then fixed with sugar formalin (HANEY and $\left.\mathrm{H}_{\mathrm{ALL}}, 1973\right)$, and were counted under a microscope in the laboratory. Sampling and counting of Cladocera were duplicated at each station. Eggs in their brood chambers were also counted. Body length (from the top of the head to the posterior of the carapace) of each cladoceran individual was measured and the individual dry weight was estimated using the equations of body length-weight relationships determined by Hanazato and Yasuno (1985a) for Bosmina fatalis, Bosmina longirostris, Diaphanosoma brachyurum and Moina micrura, and by Dumont et al. (1975) for Daphnia am. bigua and Chydorus sphaericus. The weights of Ceriodaphnia cornuta and Daphnia galeata were calculated using the equations for Ceriodaphnia quadrangula (Dumont et al., 1975) and for Daphnia longispina (Hanazato, unpublished data), respectively.

For the populations of the main Cladocera (D. brachyurum, B. fatalis, B. longirostris, $D$. galeata and $C$. sphaericus) with the densities $>$ 1 individual $\cdot 1^{-1}$, the instantaneous birth rates (b) were determined according to Paloheimo (1974) as follows,

$$
b=\ln [(E / N)+1] / D
$$

where, $N$ is the number of individual per liter, $E$ is the number of eggs per liter, and $D$ is the egg development time in days. The egg development times of cladocerans at the sampling occasion were estimated from water temperature at that time using the equations determined by Hanazato and Yasuno (1985b) for B. fatalis, $B$. longirostris and $D$. brachyurum. For esti- mation of the egg development time of $C$. sphaericus, the equation by VIJVERBERG (1980) for the same species was used. Because there were no available data for estimating the egg development time of $D$. galeata, the equation for Daphnia longispina determined by Hanazato and YASuno (1985b) was used.

Because a mysid, Neomysis intermedia, has been considered an important predater for the cladoceran populations in Lake Kasumigaura (Hanazato and Yasuno, 1988), the mysid density was estimated by collecting the individuals with vertical tows from the lake bottom to the surface using $40 \mathrm{~cm}$-diameter and $194 \mu \mathrm{m}$-mesh plankton net at the same time as the zooplankton sampling. The sampling and counting of the mysids were performed in duplicate.

Chlorophyll $a$ concentration in the sampled water was determined by the UNESCO-SCOR method (UNESCO/SCOR, 1966) and was used to represent the algal biomass in the lake water.

\section{Results}

Figure 2 shows the seasonal changes in the density of cladoceran species at Sta. 3 during 1986-1989. In 1986, no Cladocera was found until June except for the scant appearance of Daphnia ambigua and Bosmina longirostris (the density $<6^{-1}$ ) during January-March. Diaphanosoma brachyurum, Bosmina fatalis and Chydorus sphaericus occurred abundantly during summer fall, and their density peaks appeared in August, September and October, respectively. Their densities declined in late fall, when Daphnia galeata appeared with low densities $\left(<101^{-1}\right)$ but maintained its population until April 1987. In 1987, Moina micrura built up a large population in June. $D$. brachyurum and $B$. fatalis became dominant in August and September as in 1986, but they decreased rapidly in October. C. sphaericus, however, did not appear in this year. In 1988 and 1989, D. brachyurum, B. fatalis and $C$. sphaericus dominated the cladoceran community and the pattern of their seasonal succession was similar to that in 1986 . In both years, $B$. longirostris and $D$. galeata appeared in the late fall, and the latter maintained the large popula- 


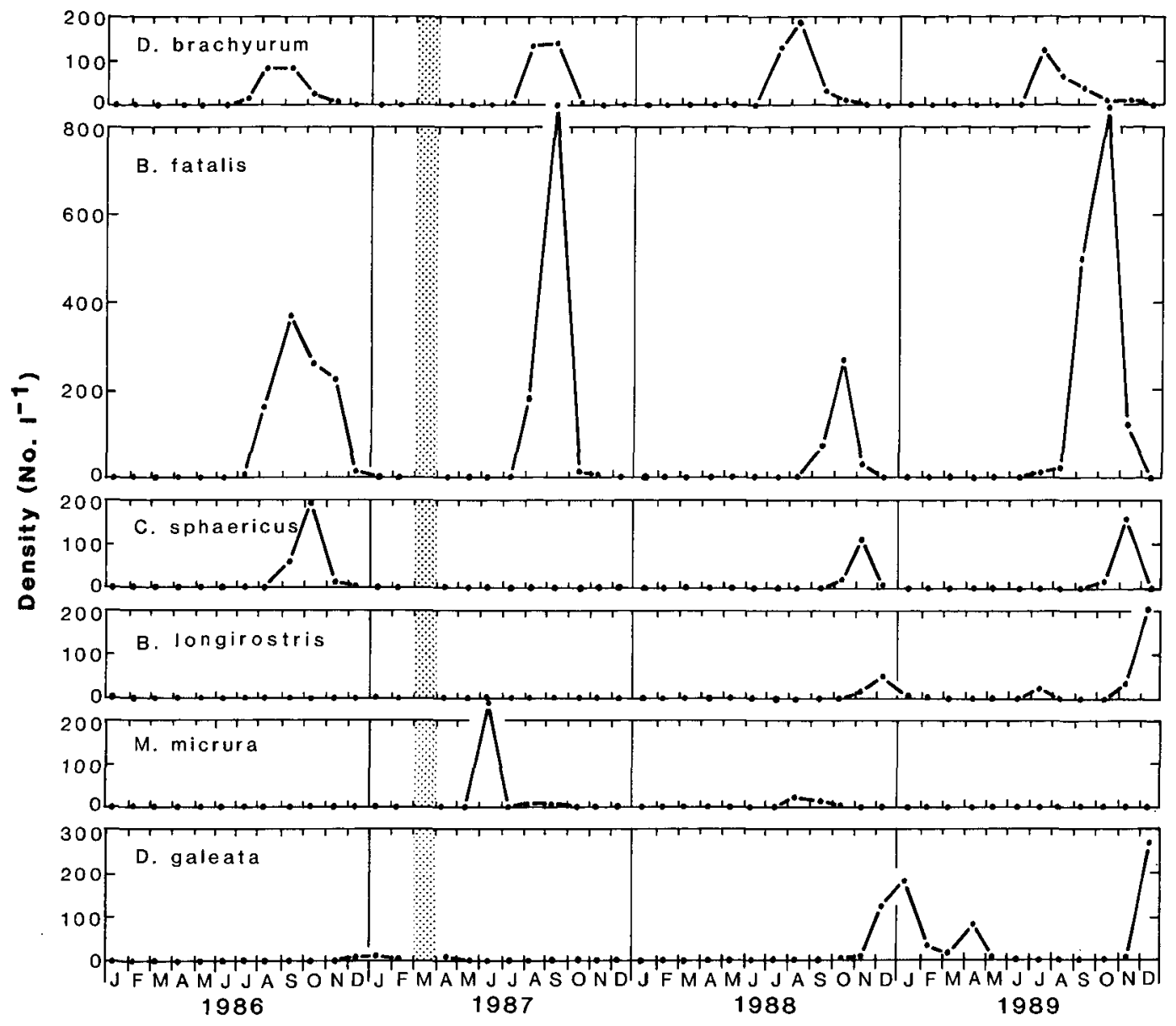

Fig. 2. Seasonal changes in the density of cladoceran species at Sta. 3 from 1986 through 1989 The shaded area in 1987 indicates the period of no observation.

tion throughout the winter and early spring.

Hanazato and Yasuno (1989a, 1989b, 1990) reported the appearance of Daphnia longispina toothed form in experimental ponds into which the bottom mud from Lake Kasumigaura was introduced. The Daphnia which appeared in the experimental ponds and the Daphnia which has been found annually in Lake Kasumigaura since the fall of 1986 are one and the same species. Hanazato and Yasuno identified the Daphnia according to Christie (1983), but his taxonomy has not been widely accepted. Recently, Flossner and Kraus (1986) described the taxonomy of the Daphnia hyalina-galeata complex. On the basis of their taxonomy, the present investigation decided that the Daphnia observed in Lake Kasumigaura should belong to $D$. galeata.

At Sta. 9, D. brachyurum, B. fatalis, $C$. sphaericus and $D$. galeata appeared abundantly (Fig. 3). D. brachyurum and $B$. fatalis predominated every summer and fall as at Sta. 3 , but their densities were lower than those at Sta. 3 except for D. brachyurum in 1986. C. sphaericus built up a large population in October 1986, but scarcely appeared thereafter. $D$. galeata showed three density peaks as at Sta. 3 (in December 1986, January 1989 and December of 1989). The peak density in December 1986 was markedly higher at Sta. 9 than at Sta. 3. In the other seasons, however, $D$. galeata was less abundant at Sta. 9. M. micrura and $B$. longirostris were found at Sta. 9. as well as at Sta. 3 , but their densities were usually below 10 


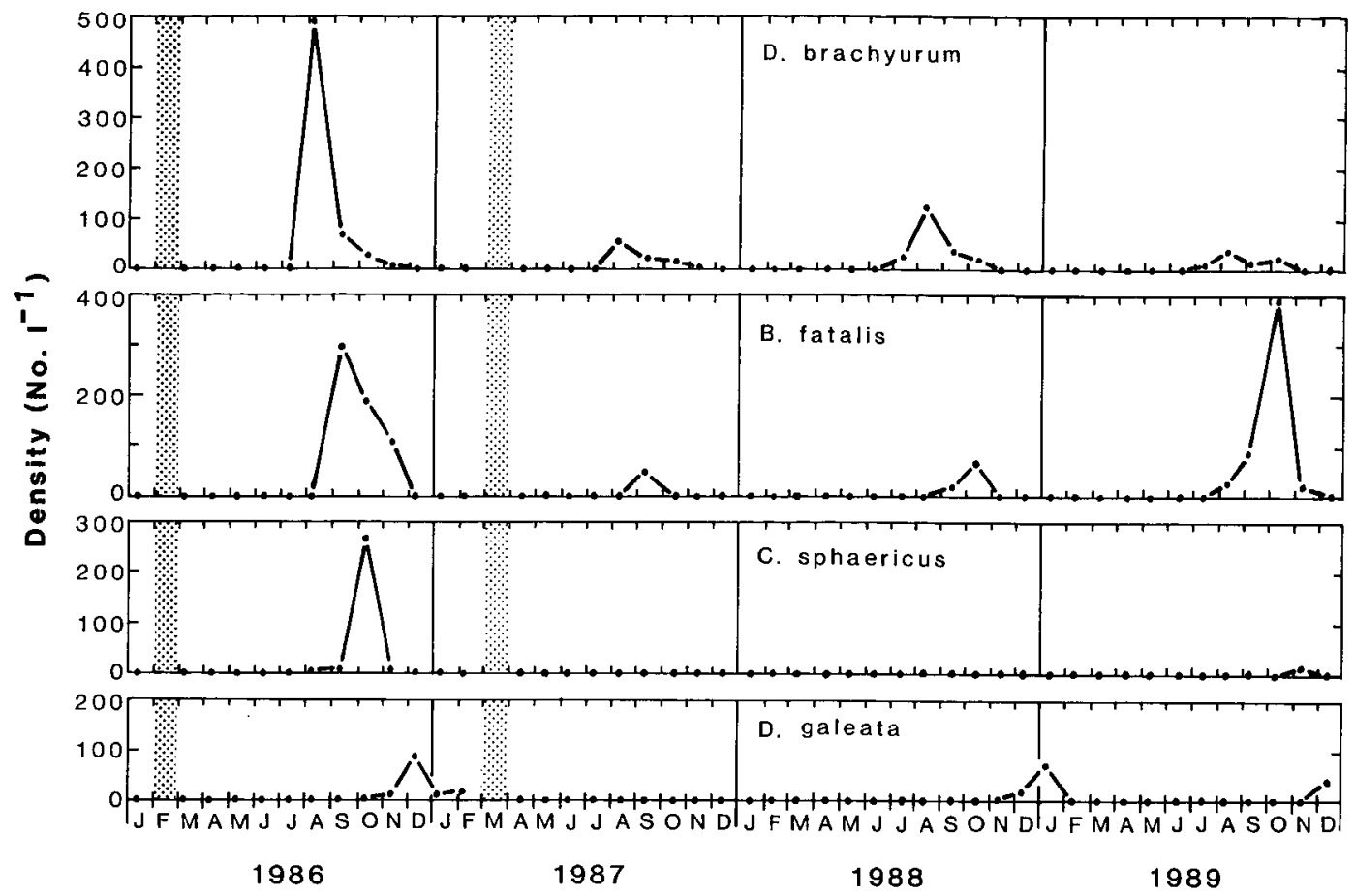

Fig. 3. Seasonal changes in the density of cladoceran species at Sta. 9 from 1986 through 1989. The shaded areas in 1986 and 1987 indicate periods of no observation.

$1^{-1}$

At Sta. 3, the instantaneous birth rates of $D$. brachyurum and $B$. fatalis became highest in July-September but declined rapidly in fall (Fig. 4). The annual highest values ranged between 0.2 and 0.3 in $D$. brachyurum, while the highest values of $B$. fatalis were above 0.4 except in 1988 . Thus, the $B$. fatalis population was more productive than the $D$. brachyurum population in summer. A similar tendency was observed at Sta. 9, but the instantaneous birth rates of cladocerans were usually lower at Sta. 9 than at Sta. 3. From fall to spring, the rates were usually small. However, D. galeata sometimes showed high rates (about 0.2) even in those seasons (e.g., in November 1988 and May 1989 at Sta.3, and February 1987 at Sta. 9).

The highest cladoceran biomass was found in September or October of 1986, 1987 and 1989. It is mainly composed of $B$. fatalis (Fig. 5). At Sta. 9, on the other hand, the biomass usually became highest in August, when D. brachyurum was dominant. In 1988, however, the highest biomass peak appeared in December at Sta. 3 and $D$. galeata mainly established this peak. This species also elevated the cladoceran biomass greatly at Sta. 9 in the same season, but the appearance of its peak was delayed for one month, and occurred in January 1989. The abundant occurrence of $D$. galeata was again observed in December 1989 both at Stas. 3 and 9. The biomass reached a considerably high level $\left(840 \mathrm{~g} \mathrm{dry} \mathrm{wt} \cdot \mathrm{m}^{-3}\right)$ at Sta. 3.

A mysid, Neomysis intermedia, established large density peaks in spring and early summer (Fig. 6). They often appeared in fall but never became abundant (the density $<10$ individuals. $\mathrm{m}^{-3}$ ) except in the fall of 1988 at Sta. 9. The density reached 136 individuals $\cdot \mathrm{m}^{-3}$ at that time. At Sta. 3 in 1988 and at Stas. 3 and 9 in 1989 , no mysid was caught by vertical tows in the fall.

Figure 7 shows the seasonal changes in chlorophyll $a$ concentration at Stas. 3 and 9 during 1986-1989. The concentrations were minimum in January-March. At Sta. 3, the minimum concentration was $20-30 \mu \mathrm{g} \cdot \mathrm{I}^{-1}$ in $1986-1988$, but fell to $0.7 \mu \mathrm{g} \cdot 1^{-1}$ in January 1989. At Sta. 9, 


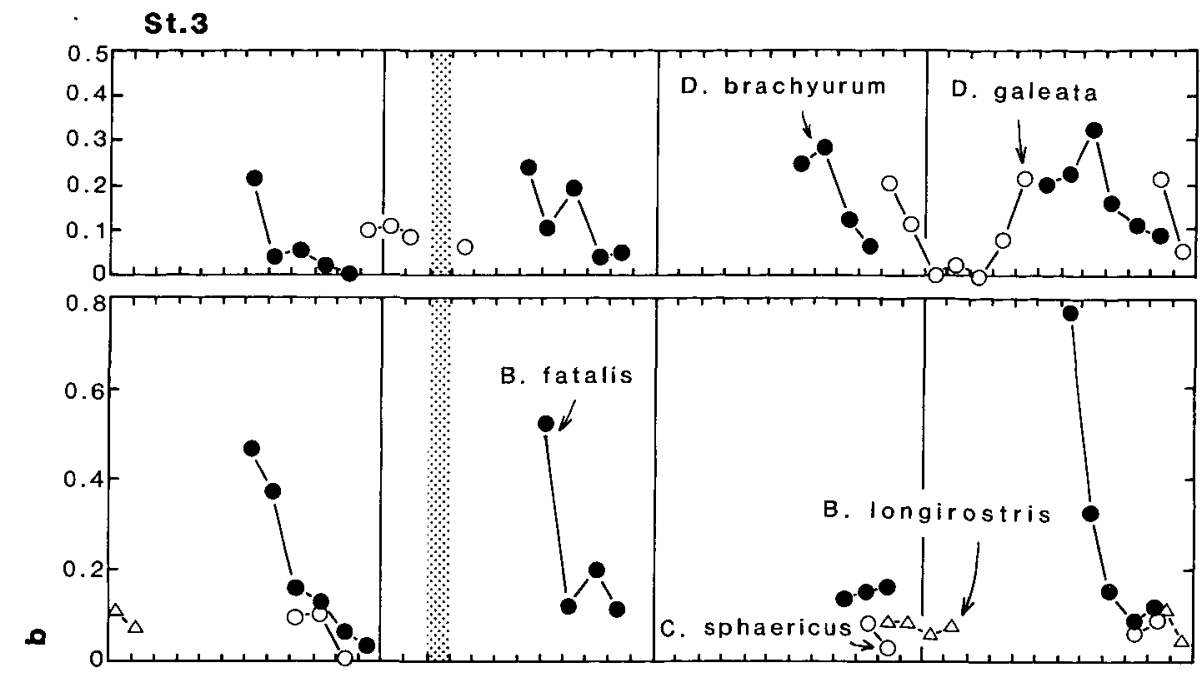

st.9
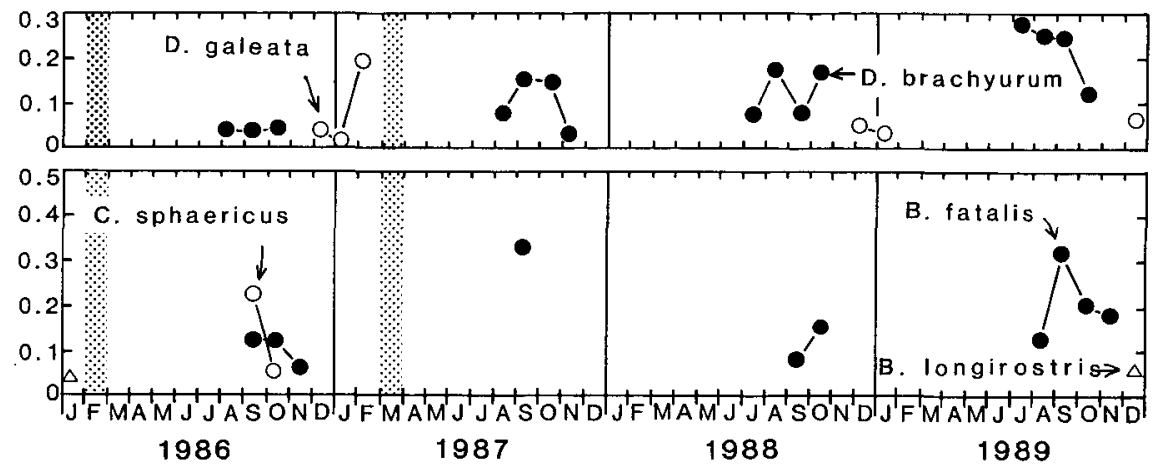

Fig. 4. Seasonal changes in the instantaneous birth rate (b) of the main cladoceran species at Stas. 3 and 9 from 1986 through 1989. The shaded areas in 1986 and 1987 indicate periods of no observation.

the minimum concentration was below $6 \mu \mathrm{g} \cdot \mathrm{l}^{-1}$ in 1986, 1987 and 1989, while it became markedly higher $\left(21.7 \mu \mathrm{g} \cdot \mathrm{I}^{-1}\right)$ in 1988 . From spring to fall, the concentration was maintained at a high level (around $100 \mu \mathrm{g} \cdot \mathrm{l}^{-1}$ at Sta. 3 and around 50 $\mu \mathrm{g} \cdot 1^{-1}$ at Sta. 9). In 1986, the chlorophyll $a$ concentration fluctuated at around $150 \mu \mathrm{g} \cdot \mathrm{l}^{-1}$ at Sta. 3, which was apparently higher than in the other years. Blue-green algae bloomed from July to October; Anabaena dominated in July and Microcystis in August-October (Takamura and Yasuno, in prep.). From late fall to spring, Cyclotella, Synedra and Cos. cinodiscus were abundant.

The relationships between chlorophyll $a$ concentration and total cladoceran biomass are presented in Fig. 8. No correlation is noted between their patterns in Fig. 8a, in which the data for all seasons (January-December) were plotted. The data were then classified into two groups in terms of the season: blooming season of blue-green algae (July-October) and the remaining seasons (non-blooming season for blue-green algae; November-June). They were plotted in Figs. 8b and 8c. The chlorophyll $a$ concentration tended to become low when the cladoceran biomass was high during November-June (Fig. 8c), a relationship not recognized in the blooming season of bluegreen algae (Fig. 8b).

\section{Discussion}

Previous studies on the zooplankton community in Lake Kasumigaura (YAsuno et al., 1977; 


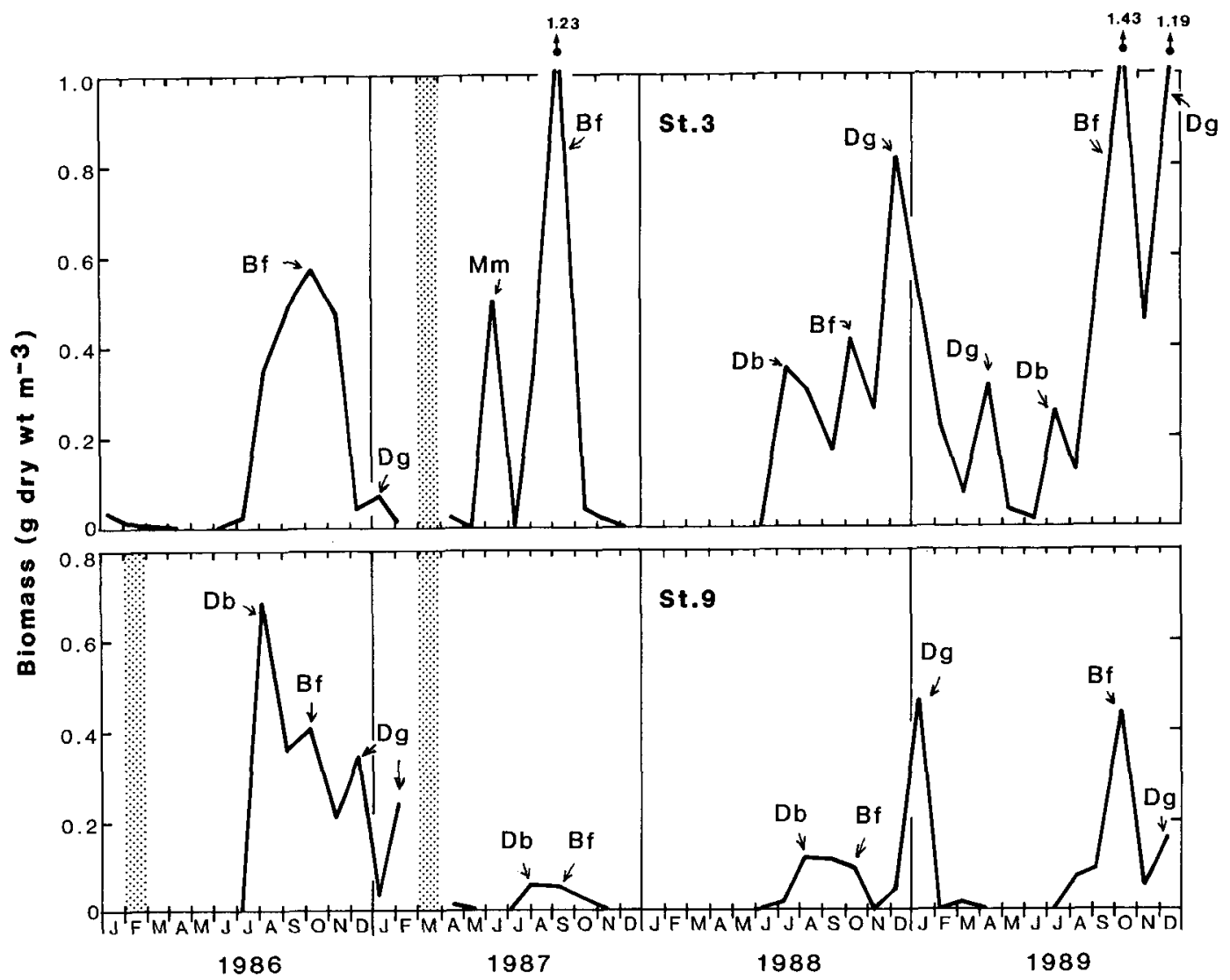

Fig. 5. Seasonal changes in the biomass of the total cladoceran species at Stas. 3 and 9 from 1986 through 1989. The shaded areas in 1986 and 1987 indicate periods of no observation. Abbreviations in the figure show the dominant species when the biomass peak appeared. $\mathrm{Bf}=$ Bosmina fatalis $; \mathrm{Db}=$ Diaphanosoma brachyurum $; \mathrm{Mm}=$ Moina micrura $; \mathrm{Dg}=$ Daphnia galeata.

Morishita and Yasuno, 1979; Yasuno et al., 1981; Hanazato and Yasuno, 1985a, 1987a, 1988) reported the dominance of $D$. brachyurum and $B$. fatalis every summer. This was observed also in the present study. Thus, it may be concluded that the species composition in the cladoceran community is stable in summer. In contrast, the species composition during late fallspring changed from year to year. Thus, at Stas. 3 and $9, B$. fatalis and D. galeata were abundant in 1986, while cladocerans were scarcely found in 1987. In 1988 and 1989, C. sphaericus, $B$. longirostris and $D$. galeata predominated at Sta. 3 , while only $D$. galeata became abundant at Sta. 9 .

The occurrence of $D$. galeata is given special mention as the first record of the species in
Lake Kasumigaura. Species of the genus $D a$ phnia had never been found in the lake before 1983. The first colonization of Daphnia was performed by $D$. ambigua in the spring of 1984 (Hanazato and Yasuno, 1985c, 1988). The occurrence of Daphnia in Lake Kasumigaura seemed to be related to mysid predation, because the seasons when Daphnia appeared accorded well with the seasons when the mysids were absent. Before 1983, the mysids established large populations twice a year, in spring and fall, while no Cladocera were found from fall through spring (HANAzATO and Yasuno, 1988). Since 1983, however, the mysids have often failed to establish populations. Their absence certainly encouraged the colonization of the daphnids. 


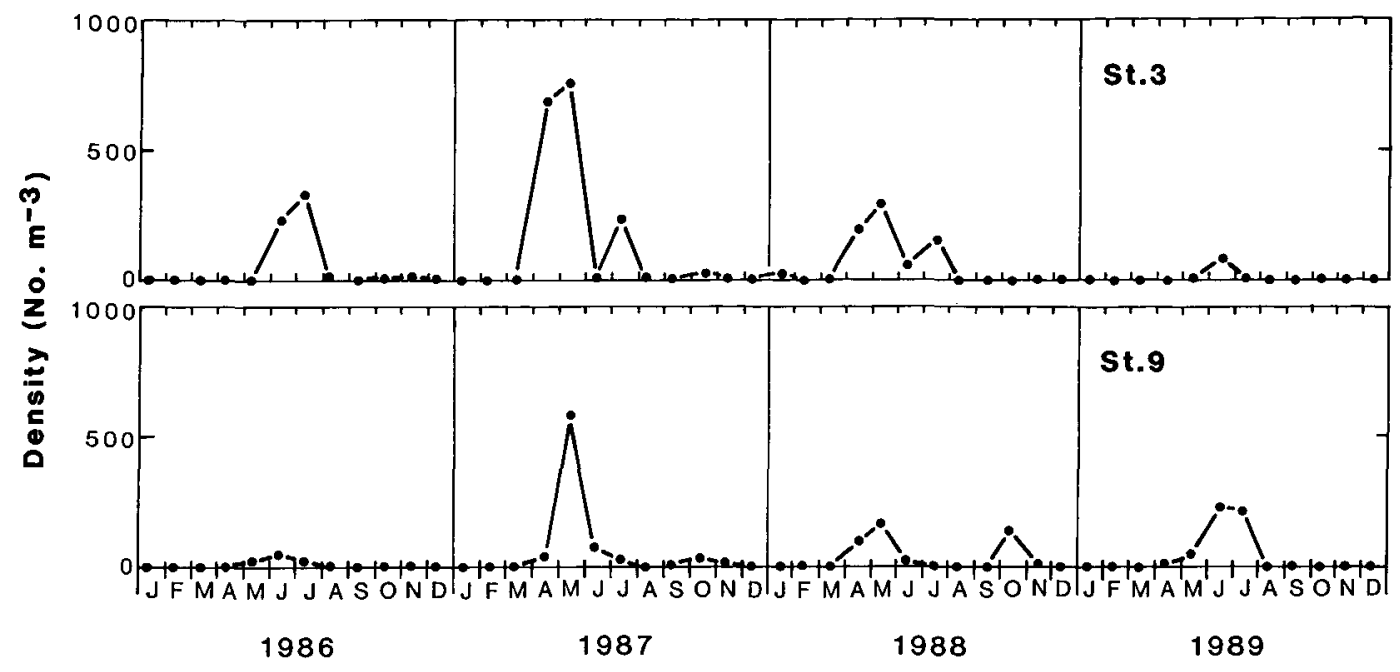

Fig. 6. Seasonal changes in the density of Neomysis intermedia at Stas. 3 and 9 from 1986 through 1989.

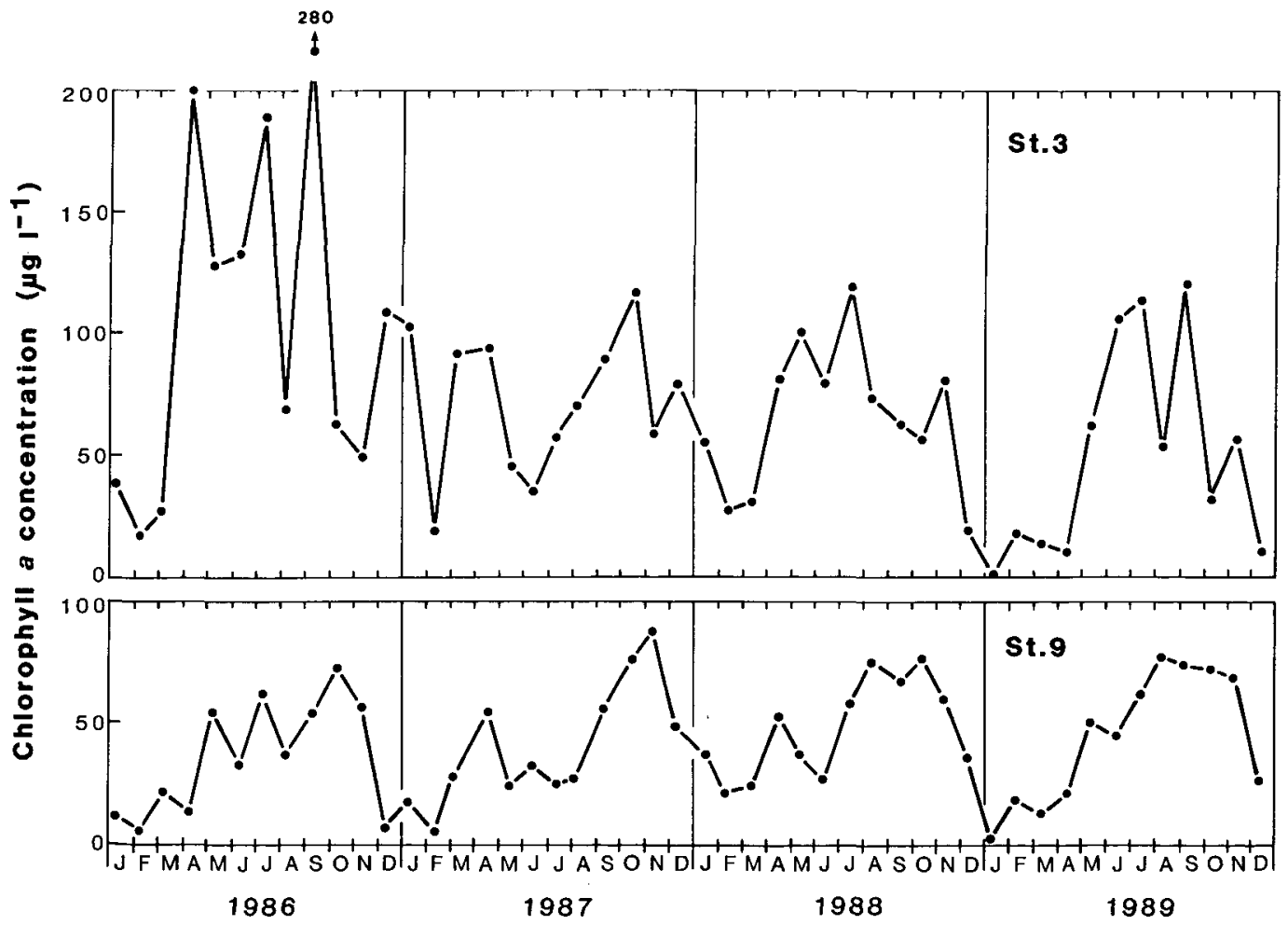

Fig. 7. Seasonal changes in chlorophyll $a$ concentration in the water column (from surface to 2 $\mathrm{m}$ deep) at Stas. 3 and 9 from 1986 through 1989. 


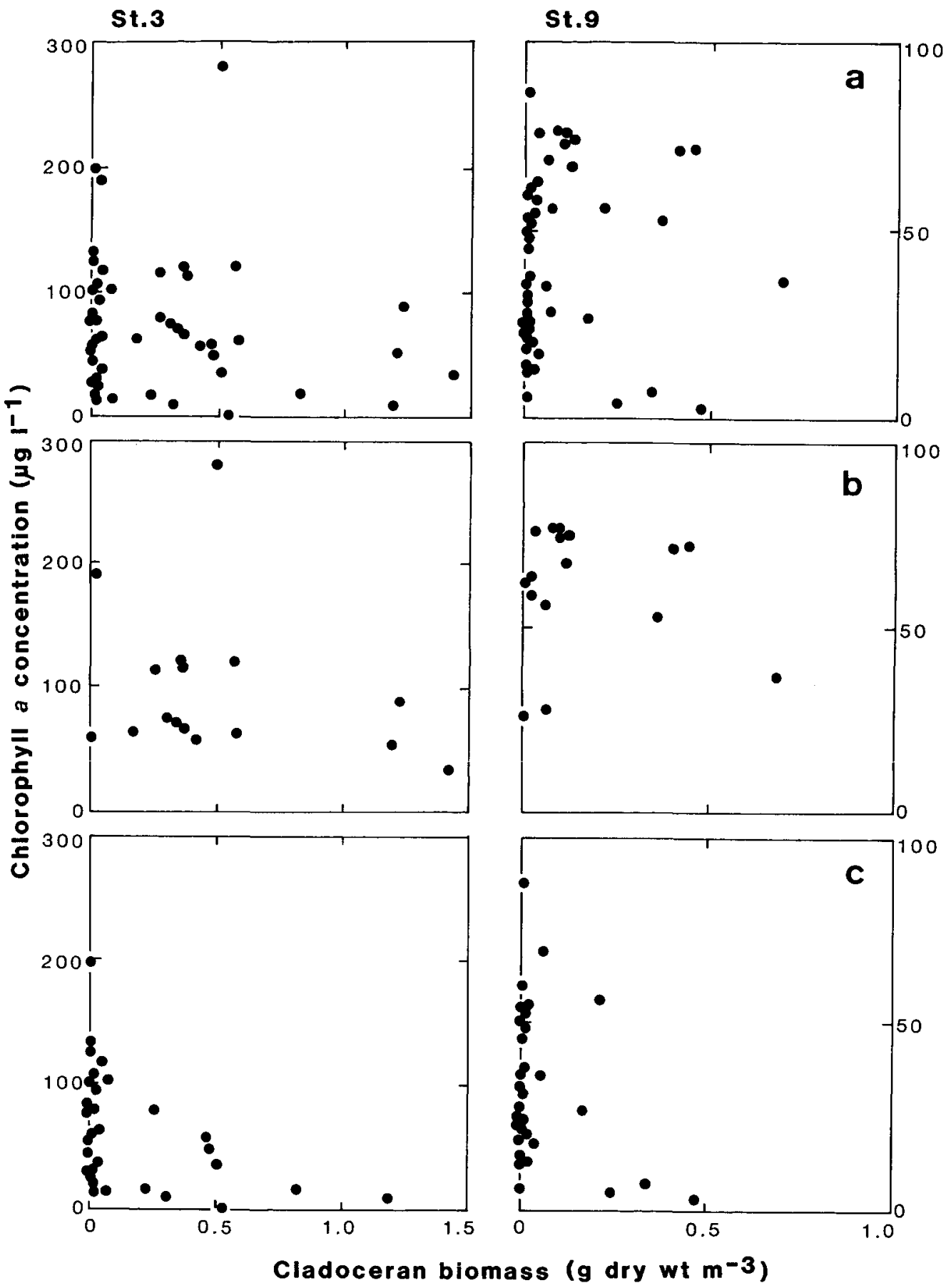

Fig. 8. Relationships between chlorophyll $a$ concentration and total cladoceran biomass during all seasons (a), blooming season of blue-green algae (July-October; b), and no blooming season of the blue-green algae (November-June; c) in 1986-1989. 
The mysid predation might also suppress other cladoceran populations, since B. fatalis, $C$. sphaericus and $B$. longirostris built up large populations in the fall of 1986, 1988 and 1989 at Sta. 3 and the fall of 1986 and 1989 at Sta. 9, when mysids scarcely appeared, whereas few cladocerans occurred in autumn of the other years, when mysids were usually abundant. Mysids have a strong predation impact on cladoceran populations and often eliminate various cladoceran species from lakes (Richards et al., 1975; Goldman et al., 1979; Rieman and Falter, 1981; Langeland, 1988). In Lake Stugusjoen (Norway), Cladocera was scarce when the biomass of mysids (Mysis relicta) was reportedly high (50-300 mg dry wt $\mathrm{m}^{-2}$ ) (Langeland, 1988). The biomass of Neomysis in Lake Kasumigaura was much higher: the density peaks of mysids at Stas. 3 and 9 during the present study period were 800 3,000 individuals $\cdot \mathrm{m}^{-2}$, which approximately equal 500-2,000 $\mathrm{mg}$ dry $\mathrm{wt} \cdot \mathrm{m}^{-2}$ (ToDA, personal communication). Hanazato and Yasuno (1988) suggested that in Lake Kasumigaura from 1980 to 1985 , the cladoceran densities during fall to spring were mainly controlled by mysid predation. This may well be true of the cladoceran community during 1986-1989.

Cladocerans are important grazers on phytoplankton and suppress the phytoplankton biomass in many lakes. Therefore, a negative correlation between cladoceran abundance and phytoplankton biomass has often been observed in various water bodies (OLRIK et al., 1984; LAMPERT, 1988). In Lake Kasumigaura, the negative correlation between them was not detected if the data during all seasons (January-December) or during blooming season of blue- green algae (July-October) were plotted (Fig. 8). However, when the data during November- June were plotted, a marked negative correlation appeared both at Stas. 3 and 9. These results may suggest that the biomass of the blue-green algae was not affected by the grazing of cladoceran zooplankton probably because the algae were inedible for cladocerans. In contrast, during November- June, the algal biomass decreased when cladocerans became abundant. In particular, chlorophyll $a$ concentration became very low when $D$. galeata established large populations (in December 1988-January 1989 and December 1989 at Sta. 3; in December 1986, February 1987 and January 1989 at Sta. 9: see Figs. 5 and 7). D. galeata certainly reduced the algal abundance. Daphnia is the most efficient grazer on phytoplankton, and often leads to a dramatic reduction in phytoplankton biomass in lakes (Shapiro, 1980). The spring clear phase in lakes is a well known phenomenon that Daphnia reduced the phytoplankton biomass (LAmpert et al., 1986). Haney (1973) and JARVIS (1986) measured in situ community grazing rate of zooplankton and reported that Daphnia was the most important grazer and the community grazing rate exceeded $100 \%$ when the density of Daphnia reached to about 50-100 individuals $\cdot 1^{-1}$. Such high daphnid density was often attained by $D$. galeata in Lake Kasumigaura. Thus, $D$. galeata certainly exerted a great influence on phytoplankton community in the lake.

The biomass and instantaneous birth rates of cladocerans were usually highest in summer, reflecting its peak production. The previous studies (Hanazato and Yasuno, 1985a, 1987a) also reported that the highest biomass and production of cladocerans occurred in summer in Lake Kasumigaura. These results indicate the large food supply available to zooplankton in this season. Summer was the season when blue-green algae, mostly Microcystis spp., bloomed heavily. Microcystis has been considered to be inedible for cladoceran zooplankton (Sirenko et al., 1976; Lampert, 1981, 1982; Hanazato and Yasuno, 1984, 1987b; Nizan et al., 1986). However, Hanazato and Yasuno (1987b, 1987c) demonstrated that Microcystis becomes available as cladoceran food when it is decomposed. This decomposition in summer may assure the food supply for the cladocerans in Lake Kasumigaura, as earlier suggested by Hanazato and Yasuno (1987a, 1987b). Thus, the detritus food-chain seemed to be the main energy channel from phytoplankton to zooplankton in summer. Recently, Hanazato and 
Watanabe (in prep.) emphasized the importance of bacteria in the decomposition of Microcystis as food for zooplankton.

Hanazato and Yasuno (1987a) showed that the productivity of cladocerans was higher in the shallower regions than in the deeper regions of Lake Kasumigaura. They hypothesized that the resuspension of detritus from the bottom, which could be utilized by zooplankton as their food, would be correlated with the water depth, and consequently the shallower regions could be more productive for zooplankton than the deeper regions. In the present study, the biomass and instantaneous birth rates of cladocerans also tended to be higher at the shallower Sta. 3 than at the deeper Sta. 9. The present results support HaNazato and Yasuno (1987a) hypothesis.

\section{Acknowledgments}

We are indebted to the members of the Lake Kasumigaura research group in the National Institute for Environmental Studies for their assistance in the field work. Thanks are also due to Dr. J. URABE for his valuable comments on the taxonomy of Daphnia, and to Dr. H. TODA for his helpful suggestions.

\section{摘 要}

\section{霞ヶ浦における枝角類動物プランクトン群集の変 動(1986-1989)：Daphnia galeata の出現とそれ が植物プランクトン量に及ぼす影響}

1986-1989の 9 年間にわたり霞ヶ浦における枝角 類動物プランクトン群集の変動を調ベた。枝角類 群集の種組成は夏には安定して抢り, Diaphanosoma brachyurum と Bosmina fatalis が優 占した。一方, 秋から春にかけては変動が大きく, これにはイサザアミの捕食が大きく関与している ように思われた。最も顕著な種組成の変化はDaphnia galeata の出現である。この種は 1986 年以前に は霞ヶ浦では観察されていなかった。D. galeataの 現存量が高くなったときにはクロロフィル量がか なり低くなった。Daphnia が攝食活動によって植 物プランクトン量を大きく減少させたものと考え られる。霞ヶ浦の枝角類の増殖速度は夏に高く, また水深の浅い地点で深い地点よりも高くなる傾 向があり, 浅い地点では動物プランクトンの生産
量が高いことが推察された。

\section{References}

Christie, P. (1983): A taxonomic reappraisal of the Daphnia hyalina complex (Crustacea: Cladocera):an experimental and ecological approach. J. Zool. London, 199: 75-100.

Dumont, H. J., I. VAN DE Velde and S. Dumont (1975): The dry weight estimate of biomass in selection of Cladocera, Copepoda and Rotifera from the plankton, periphyton and benthos of continental water. Oecologia, 19: 75-97.

Flossner, D. and K. Kraus (1986): On the taxonomy of the Daphnia hyalina-galeata complex (Crustacea: Cladocera). Hydrobiologia, 137: 97-115.

Goldman, C. R., M. D. Morgan and S. T. Threlkeld (1979): A population dynamics analysis of the cladoceran disappearance from Lake Tahoe, California - Nevada. Limnol. Oceanogr., 24: 289- 297.

Hanazato, T. and M. Yasuno (1984): Growth, reproduction and assimilation of Moina ma crocopa fed on Microcystis and/or Chlorella. Jap. J. Ecol., 34: 195-202.

Hanazato, T. and M. Yasuno (1985a): Population dynamics and production of cladoceran zoo. plankton in the highly eutrophic Lake Kasumigaura. Hydrobiologia, 124: 13-22.

Hanazato, T. and M. Yasuno (1985b): Effect of temperature in the laboratory studies on growth, egg development and first parturition of five species of Cladocera. Jpn. J. Limnol., 46: 185-191.

Hanazato, T. and M. Yasuno (1985c): Occurrence of Daphnia ambigua Scourfield in Lake Kasumigaura. Jpn. J. Limnol., 46: 212-214.

Hanazato, T. and M. Yasuno (1987a): Characteristics of biomass and production of cladoceran zooplankton in Lake Kasumigaura. Jpn. J. Limnol., 48: S45-S57.

HANAZATO, T. and M. YASUNo (1987b): Evaluation of Microcystis as food for zooplankton in a eutrophic lake. Hydrobiologia, 144: 251-259.

HANAZATO, T. and M. Yasuno (1987c): Experimental studies on competition between Bosmina longirostris and Bosmina fatalis. Hydrobiologia, 154: 189-199.

Hanazato, T. and M Yasuno (1988): Impact of predation of Neomysis intermedia on a zooplankton community in Lake Kasumigaura. Verh. Internat. Ver. Limnol., 23: 2092-2098.

HaNAZATO, T. and M. YASUNo (1989a): Zooplan- 
kton community structure driven by vertebrate and invertebrate predators. Oecologia, 81: 450458.

Hanazato, T. and M. Yasuno (1989b): Influence of overwintering Daphnia on spring zooplankton communities: An experimental study. Ecol. Res., 4: 323-338.

Hanazato, T. and M. Yasuno (1990): Insights into competition in zooplankton communities der. ived from studies using experimental ponds. Verh. Internat. Ver. Limnol., 24.

HANEY, J. F. (1973): An in situ examination of the grazing activities of natural zooplankton communities. Arch. Hydrobiol., 72: 87-132.

Haney, J. F. and D. J. Hall (1973): Sugar-coated Daphnia: a preservation technique for Cladocera. Limnol. Oceanogr., 18: 331-333.

JARVIS, A. C. (1986): Zooplankton community grazing in a hypertrophic lake (Hartbeespoot Dam, South Africa). J. Plankton Res., 8: 1065- 1078.

LAMPERT, W. (1981): Inhibitory and toxic effects of blue-green algae on Daphnia. Int. Revue ges. Hydrobiol., 66: 285-298.

LAMPER'T, W. (1982): Further studies on the inhibitory effect of the toxic blue-green Microcystis aeruginosa on the filtering rate of zooplankton. Arch. Hydrobiol., 95: 207-220.

LAMPERT, W. (1988): The relationship between zooplankton biomass and grazing: A review. Limnologica (Berlin), 19: 11-20.

Lampert, W., W. Fleckner, H. Rai and B. E. TAYLOR (1986): Phytoplankton control by grazing zooplankton: A study on the spring clearwater phase. Limnol. Oceanogr., 31: 478-490.

LANGELAND, A. (1988): Decreased zooplankton density in a mountain lake resulting from predation by recently introduced Mysis relicta. Verh. Internat. ver. Limnol., 23: 419-429.

Morishita, M. and M. Yasuno (1979): Seasonal change and horizontal distribution of zooplankton at Takahamairi Bay in Lake Kasumigaura. Res. Rep. Natl. Inst. Environ. Stud., 6: 155-170. (in Japanese with an English abstract).

Nizan, S., C. Dimentman and M. Shiro (1986): Acute toxic effects of the cyanobacterium Microcystis aeruginosa on Daphnia magna. Limnol. Oceanogr., 31: 467-502.

Olrik, K., S. Lundoer and K. Rasmussen (1984): Interaction between phytoplankton, zooplan- kton, and fish in the nutrient rich shallow Lake Hjarbaek Fjord, Denmark. Int Revue Ges. Hydrobiol., 69: 389-405.

Paloheimo, J. E. (1974): Calculation of instantaneous birth rate. Limnol. Oceanogr., 19: 692-694.

Richards, R. C., C. R. Goldman, T. C. Frantz and R. WICKWIRE (1975): Where have all the Daphnia gone? The decline of a major cladoceran in Lake Tahoe, California-Nevada. Verh. Internat. Ver. Limnol., 19: 835-842.

Rifman, B. E. and C. M. Falter (1981): Effects of the establishment of Mysis relicta on the macrozooplankton of a large lake. Trans. Amer. Fish. Soc., 110: 613-620.

ShapiRo, J. (1980): The importance of trophic-level interactions to the abundance and species composition of algae in lakes. p. 105-116, In J. BARICA and L. R. Mur (eds.), Hypertrophic ecosystems, Dr. Junk BV Publishers.

Sirenko, L. A., Yu. A. Kirpenko, L. F. Lukina, O. V. Kovalenko and L. M. Zimovers (1976): Toxicity of blue- ${ }^{-}$reen algae, the causative agents of the blooming of water. Hydrobiol. J., 12: 1318.

UNESCO/SCOR (1966): Determination of photosynthetic pigments in seawater. UNESCO, Paris, 69pp.

VIJVERBERG, J. (1980): Effect of temperature in laboratory studies on development and growth of Cladocera and Copepoda from Tjeukemeer, The Netherlands. Freshwat. Biol., 10: 317-340.

Yasuno, M., M. Morishita and Y. Sugaya (1977): Benthos and zooplankton at Takahamairi Bay in Lake Kasumigaura. Res. Rep. Natl. Inst. Environ. Stud., 1: 94-107. (in Japanese).

Yasuno, M., M. Morishita and T. Hanazato (1981): Standing crop of zooplankton at Takahamairi Bay in Lake Kasumigaura. Res. Rep. Natl. Inst. Environ. Stud., 22: 149-158. (in Japanese with an English abstract).

（著者：花里孝幸，相崎守弘，国立環境研究所地域環 境研究グループ，テ 305 茨城県つくば市小野川 16-2； Takayuki Hanazato and Morihiro AizAKI, Regional Environment Division, National lnstitute for Environmental Studies, Onogawa, Tsukuba, Ibaraki 305)

Received: 18 April 1990 Accepted: 15 October 1990 